\title{
Penilaian Kemampuan Berpikir Kritis Dalam Pembelajaran Fikih Dengan Watson-Glaser Critical Thinking Appraisal (WGCTA)
}

\section{CRITICAL THINKING ABILITY ASSESSMENT IN FIKIH LEARNING WITH WATSON- GLASER CRITICAL THINKING APPRAISAL (WGCTA)}

\author{
Fathur Rohman ${ }^{1}$, Kusaeri ${ }^{2}$ \\ ${ }^{1}$ Universitas Islam Nahdlatul Ulama (UNISNU) Jepara \\ ${ }^{2}$ Universitas Islam Negeri (UIN) Sunan Ampel Surabaya \\ email: fathur_rohman@unisnu.ac.id
}

Naskah Diterima: 29 Juni 2020; Direvisi: 23 November 2020; Disetujui: 28 November 2021

\begin{abstract}
One of the competencies that became the main goals in the 2013 curriculum was critical thinking. All subjects, including Islamic Religious Education (PAI), should be able to deliver students to be able to think critically. However, critical thinking skills are not given much attention to PAI learning, especially Fiqh. Likewise, in the case of valuation, there are currently not many assessment instruments specifically developed to measure the ability to think in Fiqh learning. Therefore, this article intends to design a concept for assessing critical thinking skills by adopting the critical thinking test model developed by Watson and Glaser or commonly known as the Watson-Glaser Critical Thinking Appraisal (WGCTA). Two problems will be discussed in this paper, namely, how about critical thinking in Fiqh learning, and how is the concept of Critical Thinking Ability Assessment in Fiqh learning with WGCTA. The result of this paper is a sample assessment of critical thinking skills in Fiqh learning based on five indicators in the WGCTA test, namely inference, recognition of assumptions, deduction, interpretation, and evaluation of argument.
\end{abstract}

Keywords: Assessment; Critical thinking; Fiqh; WGCTA

\begin{abstract}
Abstrak
Salah satu kompetensi yang menjadi tujuan utama dalam kurikulum 2013 adalah berpikir kritis. Semua mata pelajaran, tak terkecuali PAI, hendaknya dapat mengantarkan peserta didik untuk mampu berpikir kritis. Meski demikian, kemampuan berpikir kritis tampaknya tidak banyak menjadi perhatian dalam pembelajaran PAI, khususnya fikih. Begitu pula, dalam hal penilaian, saat ini banyak instrumen penilaian yang secara khusus dikembangkan untuk mengukur kemampuan berpikir dalam bidang fikih. Oleh karena itu, artikel ini bermaksud untuk merancang sebuah konsep penilaian kemampuan berpikir kritis dengan mengadopsi model tes critical thinking yang dikembangkan oleh Watson dan Glaser atau lazim disebut dengan Watson-Glaser Critical Thinking Appraisal (WGCTA). Ada dua permasalahan yang akan dibahas dalam tulisan ini yakni, bagaimana kemampuan berpikir kritis dalam pembelajaran fikih, dan bagaimana penilaian kemampuan berpikir kritis dalam pembelajaran fikih dengan WGCTA. Hasil dari tulisan ini adalah sampel penilaian kemampuan berpikir kritis dalam fikih berdasarkan lima indikator dalam tes WGCTA yaitu penarikan kesimpulan, pengenalan asumsi, deduksi, interpretasi, dan evaluasi argumen.
\end{abstract}

Kata kunci: Berpikir kritis; Fikih; Penilaian; WGCTA 


\section{PENDAHULUAN}

Revolusi industri 4.0 yang sering disebutsebut sebagai era disruptif telah menghadirkan banyak perubahan dengan sangat cepat, bahkan tidak pernah terbayangkan sebelumnya oleh manusia. Menghadapi perubahan tersebut, satusatunya cara bagi manusia untuk terus survive tak lain adalah dengan menyesuaikan diri dengan perubahan itu (Schwab, 2017). Oleh karena itu, salah satu kemampuan yang dibutuhkan untuk menghadapi revolusi industri tersebut adalah kemampuan memecahkan berbagai masalah yang semakin kompleks. Kemampuan memecahkan masalah sendiri tergantung pada banyak faktor. Namun, para ahli meyakini bahwa berpikir kritis merupakan salah satu kemampuan terpenting dalam pemecahan masalah, baik dalam bidang pendidikan, pekerjaan, maupun kehidupan sehari-hari (Fajrianthi, Hendriani, \& Septarini, 2016).

Pemikiran kritis bisa dikatakan sebagai pondasi di mana semua keputusan harus diambil dan merupakan keterampilan yang diinginkan oleh para penyedia kerja di era 4.0 (Bandyopadhyay \& Szostek, 2019). Kemampuan berpikir kritis merupakan salah satu dari empat kompetensi yang dibutuhkan di abad 21. Empat kompetensi tersebut mencakup critical thinking and problem solving, communication, collaoration, creativity and innovation atau disebut "The 4C's". Untuk menghadapi tuntutan itu pula, pemerintah Indonesia mengembangkan kurikulum 2013 yang didesain dengan mengadaptasi konsep keterampilan abad 21 (Anazifa \& Djukri, 2017).

Permendikbud No. 81 A tahun 2013 tentang Implementasi Kurikulum telah mengamanatkan bahwa kurikulum harus mampu menjawab tantangan dan kebutuhan masa depan agar peserta didik mampu hidup dalam masyarakat global, salah satunya adalah kemampuan berpikir kritis dalam pembelajaran (Mendikbud RI, 2013). Amanat ini diperkuat oleh Permendikbud No. 36 tahun 2018 bahwa kurikulum 2013 dikembangkan dengan penyempurnaan beberapa pola pikir termasuk penguatan pada pola pembelajaran kritis (Mendikbud RI, 2018).

Dalam konteks pembelajaran PAI, kemampuan berpikir kritis juga menjadi salah satu kemampuan yang ditekankan dalam kurikulum 2013. Keputusan Menteri Agama No. 183 tahun 2019 tentang Kurikulum Pendidikan Agama Islam dan Bahasa Arab pada Madrasah menegaskan bahwa salah satu alasaan pengembangan kurikulum 2013 dalam mata pelajaran PAI dan Bahasa Arab adalah untuk mengembangkan pola pembelajaran kritis dan solutif. Maka, pembelajaran PAI kurikulum 2013 harus mampu mengakomodir kemampuan berpikir kritis peserta didik. Untuk itu, KMA menetapkan bahwa kemampuan berpikir kritis menjadi salah satu kompetensi inti yang harus dicapai dalam setiap mata pelajaran PAI yang meliputi akidah akhlak, AlQur'an hadits, fikih, dan SKI (Menteri Agama Republik Indonesia, 2019).

Khusus dalam pembelajaran fikih, kemampuan berpikir kritis dalam arti berpikir yang sehat, sistematis, dan analitis memiliki peranan yang sangat penting dalam mempelajari fikih. Hal ini karena akal ( $\left.r a^{\prime} y u\right)$ merupakan salah satu sumber sekaligus metode dalam istinbath hukum-hukum fikih (Walbridge, 2011). Dalam khazanah fikih, dikenal metode-metode istinbath hukum berbasis pemikiran seperti qiyas, istishab, istihsan, sadd al-dzari'ah dan sebagainya. Begitu pula, mempelajari fikih secara komprehensif, tidak akan berhasil tanpa disiplin lain seperti ushul fikih dan qawa'id fikih yang notabene merupakan ilmu berbasis penalaran (Jafar, 2016). Pendek kata, kemampuan berpikir merupakan salah satu unsur vital dalam mempelajari fikih, sehingga berpikir kritis juga sangat dibutuhkan dalam memahami fikih.

Kendati berpikir kritis menjadi salah satu Kompetensi Inti dalam PAI, termasuk fikih, namun pada umumnya pembelajaran PAI dengan penekanan pada kemampuan berpikir kritis, tidak dibarengi dengan adanya penilaian yang memadai. Penilaian otentik sebagai model baku penilaian Kurikulum 2013 yang dianggap lebih komprehensif, nyatanya tidak banyak mengeksplor kemampuan berpikir kritis dalam pembelajaran. Kalaupun sampai kesana, kemungkinan besar hasil pengukurannya kurang valid dan reliabel sebagaimana kelemahan penilaian otentik itu sendiri (Mustikarani \& Ruhimat, 2018). Padahal, penilaian merupakan salah tahapan krusial 
dalam pendidikan untuk menyelidiki capaian kompetensi peserta didik. Hasil penilaian yang valid bisa menjadi parameter untuk peningkatan kompetensi tersebut dalam pembelajaran. Dengan bahasa lain, jika kompetensi peserta didik tidak bisa diukur dengan jelas, maka itu akan mempengaruhi arah pembelajaran ke depan (Baird, Andrich, Hopfenbeck, \& Stobart, 2017).

Jika melihat berbagai kajian dan literatur, pembahasan tentang penilaian kemampuan berpikir kritis dalam ranah pembelajaran PAI, khususnya fikih, tampaknya belum banyak diminati. Hanya ada beberapa kajian tentang penilaian kemampuan berpikir kritis, seperti kajian Bahri dan Supahar yang menyusun instrumen tes terintegrasi agama dan sains untuk mengukur kemampuan berpikir kritis dalam pembelajaran PAI SMA (F. M. Bahri \& Supahar, 2019) atau Taufiqurrahman dkk, yang menyusun instrumen pengukuran higher order thinking skills (HOTS) dalam PAI (Taufiqurrahman, Heryandi, \& Junaidi, 2018). Oleh karena itu, penting kiranya untuk mengembangkan sebuah instrumen tes yang tepat untuk mengukur kemampuan berpikir kritis, mengingat betapa pentingya kemampuan tersebut di era modern khususnya untuk menghadapi revolusi industri.

Berdasarkan latar belakang tersebut, penulis mencoba untuk menyusun sebuah konsep penilaian kemampuan berpikir kritis dalam pembelajaran fikih. Adapun model penilaian yang diadopsi adalah model penilaian kemampuan berpikir kritis milik Watson dan Glaser atau biasa disebut Watson-Glaser Critical Thinking Appraisal (WGCTA). Model penilaian ini dipilih karena selain sebagai pelopor model penilaian kemampuan berpikir kritis, WGCTA juga dipandang lebih unggul dari model tes yang lain karena memiliki indikator yang relevan dan detail (Grimard Wilson \& Wagner, 1981). Untuk itu, tulisan ini akan difokuskan pada dua permasalahan yakni, 1) Bagaimana kemampuan berpikir kritis dalam pembelajaran fikih?, 2) Bagaimana model penilaian kemampuan berpikir kritis dalam pembelajaran fikih dengan WGCTA?

Sejauh penelusuran penulis, saat ini belum ditemukan, jika tidak boleh mengatakan belum ada, tulisan-tulisan yang mengkaji tentang Watson-Glaser Critical Thinking Appraisal (WGCTA) dan penggunaannya dalam ranah pendidikan agama Islam, atau secara lebih spesifik dalam bidang ilmu fikih. Oleh karena itu, tulisan ini bertujuan untuk menyusun sebuah model penilaian berpikir kritis dalam bidang fikih, dengan menerapkan model penilaian WGCTA agar dapat menjadi acuan penilaian dalam pembelajaran $\mathrm{PAI}$, khususnya pada mata pelajaran fikih.

\section{METODOLOGI}

Penelitian ini termasuk dalam jenis penelitian kualitatif, yaitu penelitian yang menggunakan pendekatan verbal, bukan angka. Penelitian ini berupaya untuk mengkaji model tes berpikir kritis dan implementasinya dalam penilaian kemampuan berpikir kritis dalam materi fikih. Karena itu, metode yang digunakan dalam penelitian ini adalah studi pustaka. Adapun sumber data primer yaitu Watson-Glaser Critical Appraise Appraisal UK Edition-Practice Test yang berisi panduan dan teknis penerapan WGCTA, serta contoh-contoh soal tes WGCTA. Sementara data sekunder yang berkaitan dengan pembelajaran fikih adalah buku pelajaran fikih kelas X Madrasah Aliyah pada tema ibadah serta artikel-artikel yang berkaitan dengan fikih dan pembelajaran fikih. Data-data tersebut kemudian dianalisis menggunakan teknik analisis isi dengan pendekatan transdisipliner. Pendekatan transdisipliner adalah pendekatan dengan saling mengaitkan sebuah isu yang kompleks dalam bidang tertentu dengan konsep dalam bidang yang lain untuk menemukan pemecahan masalah yang komprehensif (Riem et al., 2007). Dalam hal ini, konsep berpikir kritis yang merupakan bagian dari kajian ilmu pendidikan dan psikologi pendidikan dipadukan dengan ilmu fikih untuk memecahkan permasalahan dalam penilaian pembelajaran fikih.

\section{HASIL DAN PEMBAHASAN}

\section{Kemampuan Berpikir Kritis dalam Pembelajaran Fikih}

Setidaknya ada tiga pendekatan yang digunakan dalam memaknai berpikir kritis, yaitu filsafat, psikologi kognitif, dan pendidikan. Pendekatan filosofis berfokus pada aturan formal logika dan ada tidaknya 
pemikiran yang keliru. Dalam pendekatan ini, berpikir kritis adalah tentang memenuhi standar akurasi tertentu dalam berpikir. Sementara pendekatan psikologis kognitif lebih berfokus pada bagaimana orang berpikir, perilaku apa yang ditunjukkan oleh para pemikir kritis, dan prosedur apa yang digunakan oleh para pemikir kritis. Pendekatan ini menekankan pentingnya mempertimbangkan semua sisi masalah dan tidak menerima klaim tanpa bukti. Sedangkan pendekatan pendidikan, merujuk taksonomi Bloom tentang level kemampuan kognitif, mulai dari pemahaman hingga evaluasi, maka kemampuan, analisis, sintesis, dan evaluasi dianggap sebagai jenis pemikiran kritis (Thonney \& Montgomery, 2019).

Namun, terlepas dari perbedaan perspektif tersebut, ada titik temu dari tiga pendekatan tersebut. Para pakar bersepakat bahwa berpikir kritis berkaitan erat dengan proses kompleks yang menuntut proses penalaran tingkat tinggi untuk mencapai hasil yang diinginkan. Berpikir kritis menuntut beberapa kemampuan yang berkaitan dengan mempertanyakan sumber informasi, menguji validitas informasi yang diperoleh, menganalisis validitasnya, dan menggambarkan penjelasan yang sesuai dengan konteks tertentu (Wechsler et al., 2018). Dengan kata lain, berpikir kritis berkaitan dengan kemampuan individu untuk bertanggung jawab atas pemikiran mereka sendiri atau informasi yang mereka peroleh dan mengembangkan kriteria atau standar yang sesuai untuk menganalisis pemikiran atau informasi tersebut ( $\mathrm{Lu} \& \mathrm{Xie}$, 2019).

Robert H. Ennis menjabarkan bahwa berpikir kritis merupakan aktifitas berpikir tingkat tinggi yang meliputi beberapa aktifitas antara lain: mengamati, menyimpulkan, mengeneralisasi, bernalar, mengevaluasi penalaran, dan sebagainya. Definisi lain menguatkan definisi Ennis tersebut bahwa berpikir kritis adalah proses disiplin intelektual yang secara aktif dan terampil mengkonseptualisasikan, menerapkan, menganalisis, mensintesis, dan mengevaluasi informasi yang dikumpulkan dari, atau dihasilkan oleh, pengamatan, pengalaman, refleksi, penalaran, atau komunikasi, sebagai panduan untuk keyakinan dan tindakan (Ennis, 2018). Tidak beda jauh dari Ennis, Facione menyatakan bahwa berpikir kritis adalah pengaturan diri dalam melakukan interpretasi, analisis, evaluasi, dan inferensi, maupun pemaparan untuk mengambil sebuah keputusan menggunakan suatu bukti, konsep, metodologi, kriteria, atau pertimbangan kontekstual yang menjadi dasar dibuatnya sebuah keputusan (Facione, 2011).

Sementara Richard Paul membedakan pemikiran kritis lemah dari pemikiran kritis kuat. Dalam arti lemah, kemampuan berpikir kritis hanya tentang orang lain, bukan diri sendiri; dan dalam arti yang kuat, kemampuan berpikir kritis menyangkut posisi, argumen, asumsi, dan pandangan diri sendiri. Bagi Paul, pemikiran kritis mencakup pengetahuan mendalam tentang diri sendiri, yang membutuhkan keberanian intelektual dan kerendahan hati. Seorang pemikir kritis yang kuat mampu memahami gambaran yang lebih besar secara holistik, untuk melihat pandangan dunia yang berbeda dalam berbagai perspektif, bukan hanya untuk mengkritik orang lain (Mason, 2007; Paul, 2018)

Berpikir kritis diyakini sebagai salah satu kemampuan paling penting dalam menjalani kehidupan. Pemikir kritis dianggap lebih mampu menjalani hidup secara dewasa yang mampu membuat keputusan berdasarkan alasan dan bukti, daripada emosi, prasangka, atau dogma (Thonney \& Montgomery, 2019). Berpikir kritis juga dipandang sebagai komponen penting dari banyak pekerjaan dengan kompleksitas menengah dan tinggi (Huber \& Kuncel, 2016). Karena itu, para pakar memandang bahwa berpikir kritis merupakan salah satu tujuan paling penting dalam pendidikan dan wajib diajarkan sebagai keterampilan hidup dan bekal bagi karir di masa depan (Burke, Sears, Kraus, \& Roberts-Cady, 2014; Vieira \& Tenreiro-Vieira, 2016).

Sayangnya, penekanan berpikir kritis dalam pendidikan Islam masih sangat rendah. Sulaiman dan Syakarofath, dengan mengutip sejumlah hasil penelitian menyatakan rata-rata pelajar dari negara-negara muslim seperti Saudi Arabia, Maroko, termasuk Indonesia mengalami kesulitan dalam berpikir kritis. Mereka masih di berada di belakang pelajarpelajar dari negara Barat dalam hal berpikir kritis. Disinyalir fenomena ini disebabkan salah 
satunya oleh tradisi pendidikan Islam yang cenderung pesimis dan menuntut kepatuhan total banyak mempengaruhi gaya berpikir peserta didik untuk tunduk tanpa banyak bertanya (Sulaiman \& Syakarofath, 2018). Lebih dari itu, sebagian umat Islam yang masih menganggap berpikir kritis sebagai sesuatu yang tabu. Islam dipandang oleh para penganutnya sebagai agama yang telah sempurna sehingga tidak boleh ada hal-hal baru. Jadi, ideologi dan praktik keagamaan islam, jikapun pernah, jarang sekali mengalami peninjauan kritis dan independen (Heyboer, 2009).

Meski demikian, anggapan di atas tidak bisa sepenuhnya dibenarkan. Nyatanya, sejarah merekam bahwa berpikir kritis telah menjadi tradisi yang berjalan di antara para intelektual muslim abad klasik. Tokoh-tokoh sekelas Ibnu Sina, Ibnu Rusyd, Al-Kindi, Al-Ghazali adalah para cendekiawan yang terlahir dari sikap kritis atas berbagai situasi yang tidak menentu saat itu. Kita tentu juga tahu bagaimana jalannya dialog kritis antar para imam madzhab seperti Imam Malik, Syafi' i, dan Ahmad yang memiliki hubungan guru murid. Kritisisme itu pula yang menjadi pondasi peradaban Islam sehingga mampu menggapai kemajuan dalam bidang keilmuan (Sulaiman \& Syakarofath, 2018).

Beberapa tradisi berpikir kritis warisan khazanah pendidikan Islam klasik bahkan masih dijumpai hingga saat ini. Salah satunya tradisi adalah munazarah yang semakna dengan kata jadal yang berarti debat atau saling beradu pikiran (Ma'luf, 1956). Menurut George Makdisi, adalah metode skolastik yang mengedepankan rasionalitas dan kritisisme yang berfungsi untuk mempersiapkan para pelajar fikih untuk dapat memberikan fatwa atau menjadi mufti. Munazarah mutlak dibutuhkan oleh mufti untuk membekali mereka dengan kemampuan berpikir dan berargumen yang berkualitas karena kualitas hasil pemikiran mereka akan dapat dinilai oleh publik. Namun, metode ini hanya mungkin diterapkan dalam ilmu fikih, dan tidak boleh diterapkan dalam ilmu kalam karena dalam sejarah Islam, praktek metode munazarah dalam ilmu kalam telah menimbulkan pertumpahan darah dan kekacauan negeri (Dalimunthe, 2019).
Hingga saat ini tradisi munazarah masih bisa kita jumpai meski dengan nama yang berbeda-beda, namun memiliki substansi yang sama. Munazarah juga biasa disebut dengan musyawarah, mudzakarah, atau yang paling populer adalah bahts al-masa'il. Tradisi ini berlaku di kalangan warga Nahdlatul Ulama (NU) untuk membahas berbagai masalah faktual yang berkaitan dengan hukum Islam beserta gagasan untuk memecahkannya. Dalam forum ini, para kiai atau ulama berkumpul untuk bertukar ide, gagasan, dan referensi untuk mencari solusi atas berbagai masalah keagamaan yang ditanyakan oleh masyarakat (Pelu, 2016).

Di pesantren salaf, sistem ini juga diterapkan dalam proses pembelajaran, khususnya dalam pembelajaran fikih. Tujuannya adalah untuk melatih para santri memecahkan masalah yang berkaitan dengan hukum Islam dengan menggunakan dalil, argumentasi, dan pola pikir yang sehat. Kecuali itu, pembelajaran dengan metode bahts almasa'il ini juga bermanfaat untuk mengoptimalkan daya nalar kritis santri dalam merespon dan memecahkan berbagai masalah terkait hukum Islam (Muqoffi, 2018; Wasik, 2014).

Dalam ilmu fikih, berpikir kritis mutlak diperlukan. Derasnya perubahan zaman telah membawa kasus-kasus hukum baru yang belum pernah terjadi di era sebelumnya di berbagai lini kehidupan, ambil contoh soal pandemi, jual beli forex, cryptocurrency, Bank ASI, dan sebagainya. Kasus-kasus semacam ini adalah kasus yang benar-benar baru dan belum pernah ditemukan padanannya di masa lalu. Untuk memecahkan masalah tersebut, sekedar hafal dan paham arti Al-Qur'an, hadits, atau kitab klasik saja tidak cukup. Perlu pemikiran kritis agar dapat menganalisis dan memecahkan masalah tersebut dengan berbagai perspektif, sehingga hukum yang dihasilkan benar-benar menjadi solusi dalam menyelesaikan masalah kehidupan umat (Jafar, 2016).

Dengan demikian, berpikir kritis bukanlah hal yang aneh dalam pembelajaran fikih. Justru berpikir kritis adalah salah satu pondasi utama dalam ilmu fikih, dan dengan begitu harus ditekankan dalam pembelajaran fikih. Munazarah atau bahts al-masa'il adalah 
bukti bahwa tradisi berpikir kritis sangat dijunjung tinggi dalam bidang fikih. Ini sekaligus menegaskan bahwa pembelajaran fikih tidak tidak boleh berhenti hanya pada level menghafal atau memahami, tetapi harus naik hingga level sintesis, analisis, hingga evaluasi yang merupakan bagian dari berpikir tingkat tinggi.

\section{Watson-Glaser Critical Thinking Appraisal (WGCTA)}

Ada beberapa tes yang dikembangkan untuk mengukur kemampuan berpikir kritis, antara lain, California Critical Thinking Skills Test, Collegiate Assessment of Academic Proficiency (CAAP), Critical Thinking Assessment Inventory, Cornell Critical Thinking Test (CCTT), dan lain-lain. Di antara sekian model tes, ada satu model tes yang paling banyak digunakan terutama dalam dunia pendidikan, yaitu Watson-Glaser Critical Thinking Appraisal (WGCTA). WGCTA banyak digunakan dalam penelitian pendidikan khususnya yang berkaitan dengan berpikir kritis di sekolah. Tidak hanya di dunia pendidikan, WGCTA juga banyak digunakan dibidang pekerjaan profesional (Indah \& Fauzan, 2019).

WGCTA merupakan model penilaian yang dapat digunakan untuk mengukur beberapa faktor utama dalam kemampuan berpikir kritis. Kelebihan model WGCTA adalah indikator yang lebih rinci dibandingkan dengan model tes kemampuan berpikir kritis yang lain. WGCTA dikembangkan oleh Goodwin Watson dan Edward Glaser pada tahun 1980 di Amerika (Danaryanti \& Lestari, 2017). Dua sahabat ini merumuskan lima indikator untuk mengukur keterampilan berpikir kritis, yaitu:

Pertama, Inference (penarikan kesimpulan) merupakan kemampuan dalam menilai tingkat probabilitas ketepatan atau kebenaran sebuah kesimpulan berdasarkan informasi yang tersedia. Bagian ini menyajikan serangkaian kesimpulan (setiap kesimpulan merupakan satu item) yang mungkin dapat diambil dari paragraf yang berisi pernyataan atau pengetahuan yang diterima secara umum. Setiap item harus dinilai dengan memilih 5 jawaban, yaitu: (a) Benar (B) jika kesimpulan tersebut benar dan berdasarkan alasan yang masuk akal; (b) Mungkin Benar (MB) jika kesimpulan tersebut lebih dekat dengan benar; (c) Data Tidak Cukup (DTC) jika belum cukup data untuk membuat keputusan berdasarkan fakta yang disajikan; (d) Mungkin Salah (MS) jika kesimpulan tersebut lebih mendekati salah; (e) Salah (S) jika kesimpulan tersebut benarbenar salah karena salah dalam menggambarkan fakta yang disajikan.

Kedua, Recognition of Assumptions (pengenalan asumsi) adalah kemampuan dalam mengidentifikasi asumsi yang tersirat pada sebuah pernyataan, masalah, atau fenomena. Di bagian ini peserta diminta "untuk memutuskan masing-masing asumsi yang diusulkan apakah perlu diterima atau tidak dengan memilih jawaba antara benar (B) dan salah (S).

Ketiga, Deduction (deduksi), kemampuan dalam menentukan apakah kesimpulan dibuat secara logis berdasarkan informasi atau data yang tersedia. Di bagian ini, disajikan sebuah premis dan untuk setiap kesimpulan (item) peserta ujian diminta untuk memutuskan apakah sesuai pernyataan yang diberikan atau tidak dengan memilih benar (B) atau salah (S) (Ennis, 1958).

Keempat, Interpretation (interpretasi) adalah kemampuan dalam menilai sebuah bukti (evidence) dan membuat keputusan apakah kesimpulan yang dihasilkan terjamin kredibilitasnya berdasarkan data yang tersedia. Di bagian ini, disajikan sebuah pernyataan dan beberapa kesimpulan lalu peserta diminta untuk memutuskan apakah setiap item benar (B) atau salah (S) sesuai pernyataan yang ada.

Kelima, Evaluation of Argument (evaluasi argumen) merupakan kemampuan dalam mengevaluasi kekuatan dan relevansi sebuah argumen terkait dengan sebuah isu atau masalah tertentu. Di sini, peserta harus memutuskan apakah alasan yang ditawarkan, baik setuju atau tidak, kuat atau lemah (Watson \& Glaser, 2002).

Model penilaian WGCTA ini sudah banyak digunakan di dunia pendidikan untuk mengukur kemampuan berpikir kritis dalam berbagai bidang studi seperti ekonomi (D’Alessio, Avolio, \& Charles, 2019), Bahasa (Khodadady \& Ghanizadeh, 2011), kedokteran (Macpherson \& Owen, 2010), atau psikologi (Burke et al., 2014). 


\section{Penilaian Kemampuan Berpikir Kritis dalam Pembelajaran Fikih dengan WGCTA}

Model tes WGCTA bisa menjadi alternatif untuk mengukur kemampuan berpikir kritis dalam pembelajaran fikih. Hal ini bisa dilihat dari lima indikator dalam tes WGCTA, yaitu Inference (penarikan kesimpulan), Recognition of Assumptions (pengenalan asumsi), Deduction (deduksi), Interpretation (interpretasi), dan Evaluation of Argument (evaluasi argumen). Lima indikator tersebut jika dicermati juga bisa ditemukan dalam logika ilmu fikih. Dengan kata lain, lima indikator WGCTA tersebut relevan diterapkan untuk mengukur kemampuan kritis dalam ilmu fikih. Maka, untuk melakukan pengukuran, lima indikator tersebut perlu di-breakdown dalam bentuk soal sebagaimana model soal dalam WGCTA. Soal tersebut, kemudian diuji validitas dan reliabilitasnya menggunakan rumus statistik dan alat bantu SPSS.
Indikator penarikan kesimpulan (inference) misalnya, adalah kemampuan dalam menilai tingkat probabilitas ketepatan atau kebenaran sebuah kesimpulan berdasarkan informasi yang tersedia. Dalam aktifitas istinbath hukum Islam seperti bahts al-masa'il misalnya, penarikan kesimpulan dilakukan sebelum penetapan hukum secara kolektif (taqrir jama'iy) berdasarkan dalil, data, dan argumen yang ada (S. Bahri, 2011; Wasik, 2014). Dengan demikian, kemampuan penarikan kesimpulan ini juga dibutuhkan dalam pembelajaan fikih untuk membekali peserta didik dengan kemampuan menarik natijah (intisari) sebuah dalil atau kesimpulan dari sebuah permasalahan yang sedang dicari solusinya. Contoh tes WGCTA pada indikator inference dalam pembelajaran fikih dapat dilihat pada Tabel 1.

Tabel 1. Contoh soal Tes WGCTA dalam Bidang Fikih pada Indikator Inference

\begin{tabular}{l} 
Soal \\
$\begin{array}{l}\text { Pernyataan } \\
\text { Covid-19 merupakan virus yang sangat berbahaya dan sangat }\end{array}$ \\
mudah menular lewat kontak fisik. Karena itu, setiap aktifitas \\
berkerumun, termasuk shalat jumat harus ditunda dulu. \\
Kesimpulan \\
1. Tidak usah shalat Jumat dan diganti shalat dhuhur karena setiap \\
orang punya kewajiban dar'u al-mafasid (mencegah \\
keburukan). \\
2. Tidak usah shalat Jumat dan diganti shalat dhuhur karena taat \\
kepada pemerintah. \\
3. Tetap shalat Jumat tetapi dengan menjaga jarak shaf sesuai \\
protokol kesehatan. \\
4. Tetap shalat Jumat dengan tetap merapatkan shaf seperti biasa \\
karena urusan agama ada di atas segalanya. \\
5. Tetap shalat Jumat karena covid-19 tidak berbahaya, buktinya \\
orang berkerumun di Mall atau pasar tidak masalah. \\
\hline
\end{tabular}

Sesuai dengan model soal WGCTA (Watson \& Glaser, 2002), bisa dilihat pada tabel di atas bahwa soal inference untuk bidang fikih juga disajikan dalam bentuk pernyataan dan beberapa alternatif kesimpulan. Untuk mengerjakannya, peserta didik diminta untuk menilai lima alternatif kesimpulan yang berbeda dengan skala benar (B), mungkin benar
(MB), data tidak cukup (DTC), salah (S), dan mungkin salah (MS).

Jika dalam tes WGCTA ada indikator pengenalan asumsi (recognition of assumptions), dalam fikih pun dikenal istilah dzann yaitu asumsi-asumsi hukum terhadap suatu masalah yang tidak ditemukan dalil pastinya. Dalam khazanah fikih juga dikenal 
istilah dalil dzanny, yaitu dalil hukum yang mengandung banyak kemungkinan makna sehingga dapat ditakwil dan dipalingkan dari makna aslinya kepada makna lain. Dengan kata lain, dalil dzanni menerima interpretasi manusia yang berbeda-beda sesuai konteks masingmasing sehingga tidak mengherankan bila menimbulkan perbedaan dalam memutuskan sebuah hukum (Haika, 2016; SA, 2015). Dengan tes pengenalan asumsi tersebut, diharapkan peserta didik akan mampu menentukan asumsi-asumsi (dzann) dalam sebuah kasus hukum Islam yang paling kuat dan sesuai dengan dalil. Contoh soal WGCTA untuk indikator pengenalan asumsi pada bidang fikih dapat dilihat pada Tabel 2.

Tabel 2. Contoh soal Tes WGCTA dalam Bidang Fikih pada Indikator Recognition of Assumptions

Soal

\section{Jawaban}

Benar

Salah

Pernyataan

Rasulullah saw. pernah bersabda dalam sebuah hadits bahwa sebenarnya tidak ada penularan penyakit.

\section{Asumsi}

1. Tidak perlu takut dengan wabah Corona karena Tuhan yang menentukan segalanya, tetapi tetap ikhtiar dengan waspada menjaga diri.

2. Berserah diri kepada Tuhan secara total karena hanya Tuhan yang kuasa menularkan Corona.

Dalam soal di atas, disajikan sebuah pernyataan berdasarkan sebuah hadis shahih beserta alternatif asumsinya. Selanjutnya, peserta didik diminta untuk menilai dua asumsi tersebut dengan menjawab "benar" untuk asumsi yang paling sesuai dengan makna dan konteks hadits atau "salah" untuk asumsi yang tidak sesuai.

Adapun deduksi (deduction) adalah kemampuan dalam menentukan apakah kesimpulan dibuat secara logis berdasarkan informasi atau data yang tersedia. Kemampuan ini akan sangat mendukung peserta didik dalam mendalami fikih. Sebab, dalam fikih, deduksi merupakan salah satu metode istidlal atau mengambil sebuah kesimpulan hukum dari dalil atau kaidah umum untuk diaplikasikan dalam masalah tertentu (Shaffat, 2010; Yasid, 2012). Penalaran deduktif dalam hukum Islam sangat populer di kalangan madzhab Syafi'i yang biasa disebut dengan qiyas atau analogi deduktif. Qiyas secara sederhana bisa diartikan dengan penetapan hukum terhadap kasus baru yang memiliki kesamaan dengan kasus terdahulu dari sisi sebab, manfaat, madlarat, atau aspek lainnya (Akbar, 2014). Contoh soal WGCTA dalam bidang fikih pada indikator deduction dapat dilihat pada Tabel 3.

Tabel 3. Contoh soal Tes WGCTA dalam Bidang Fikih pada Indikator Deduction

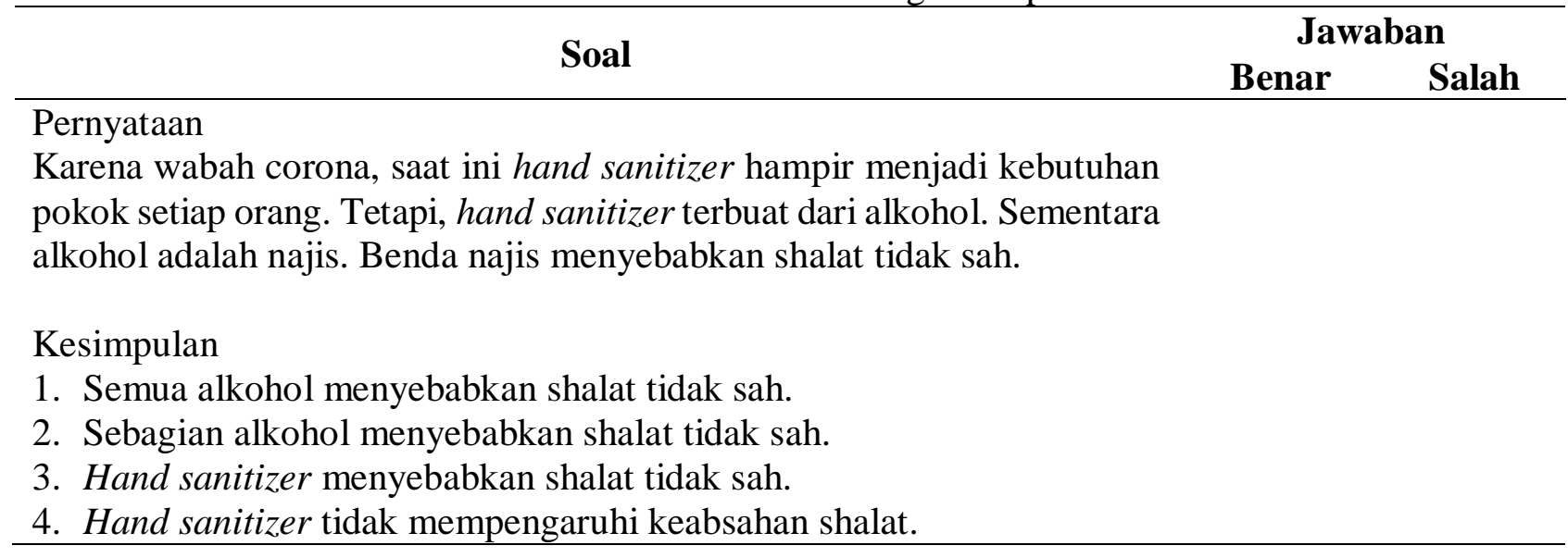


Pada tabel tersebut disajikan sebuah pernyataan yang mengandung sebuah kasus tertentu, yaitu tentang penggunaan alkohol dalam hand sanitizer dan hukum umum bahwa alkohol adalah najis. Selanjutnya, peserta didik diminta untuk menilai alternatif kesimpulan yang telah disediakan apakah benar atau salah.

Indikator WGCTA selanjutnya adalah interpretasi (interpretation) yaitu kemampuan dalam menilai sebuah bukti (evidence) dan membuat keputusan apakah kesimpulan yang dihasilkan terjamin kredibilitasnya berdasarkan data yang tersedia. Dalam fikih, interpretasi atau penafsiran terhadap sumber-sumber hukum Islam merupakan satu kemampuan yang sangat penting, karena dari sinilah biasanya rawan terjadi kesalahan. Kesalahan interpretasi terhadap suatu dalil, kaidah, atau masalah bisa mengakibatkan kesalahan dalam mengambil keputusan hukum. Karena itu, tes terhadap kemampuan interpretasi juga perlu dilakukan dalam pembelajaran fikih. Contoh soal WGCTA fikih pada indikator interpretation dapat dilihat pada Tabel 4.

Tabel 4. Contoh soal Tes WGCTA dalam Bidang Fikih pada Indikator Interpretation

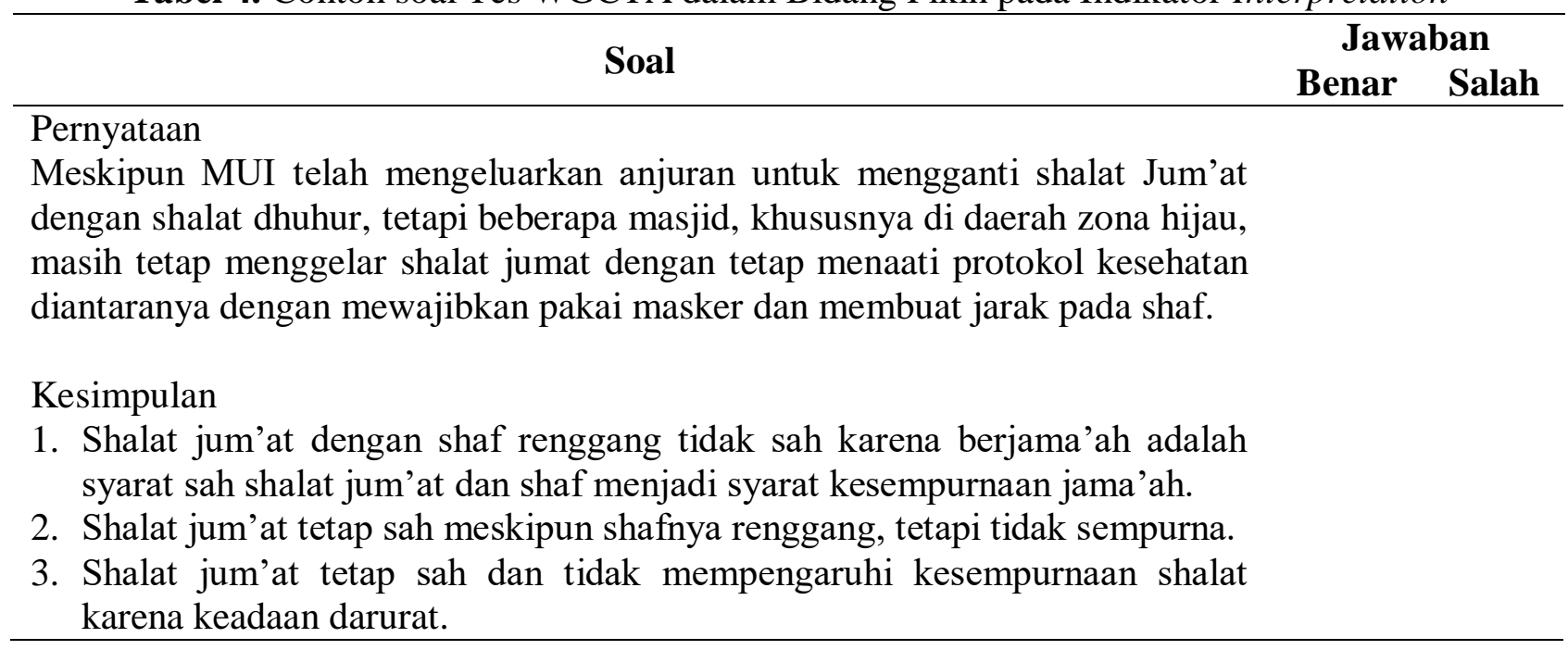

Tabel di atas menyajikan sebuah fakta tentang pelaksanaan shalat Jumat selama masa pandemi Covid-19. Berdasarkan fakta itu kemudian peserta didik diminta untuk menilai antara benar atau salah terhadap tiga kesimpulan yang ditawarkan sesuai dengan fakta yang ada. Yang benar adalah yang paling sesuai dengan fakta yang ada dan hukum fikih yang berlaku.

Indikator terakhir tes WGCTA adalah evaluasi argumen (evaluation of argument) yaitu kemampuan dalam mengevaluasi kekuatan dan relevansi sebuah argumen terkait dengan sebuah isu atau masalah tertentu. Dalam bahasa fikih, argumen sering disebut hujjah fiqhiyyah. Hujjah atau argumen turut menentukan diterimanya sebuah hukum atau tidak. Jika argumennya sesuai dengan logika ('aqliyah) dan teks (naqliyah), maka keputusan hukum bisa diterima, begitu juga sebaliknya (Ali, 2016). Maka, kemampuan ber-hujjah sesuai dengan akal dan nas, sangat penting dalam mempelajari fikih. Contoh soal WGCTA dalam ilmu fikih pada indikator evaluation of argument dapat dilihat pada tabel 5.

Tabel 5. Contoh soal Tes WGCTA dalam Bidang Fikih pada Indikator Evaluation of Argument

\begin{tabular}{cc}
\hline \multirow{2}{*}{ Soal } & Jawaban \\
& Kuat Lemah \\
\hline
\end{tabular}

Pernyataan

Si A meninggal dunia di rumah sakit karena sakit pernapasan. Tapi pihak rumah sakit belum bisa memastikan penyebab kematiannya, apakah karena Covid-19 atau sakit nafas lain, karena rumah sakit masih menunggu hasil tes Swab. Dengan alasan keamanan, pihak rumah sakit tetap menggunakan protokol pemulasaraan jenazah secara tertutup, sementara pihak keluarga tetap 


\section{Soal}

Jawaban

Kuat Lemah

ingin mengikuti semua prosesi pemakaman si A. Apa yang sebaiknya

dilakukan keluarga?

Kesimpulan

1. Pihak keluarga tetap meminta jenazah korban untuk dipulasara dan dimakamkan oleh keluarga sendiri.

2. Pihak keluarga mempercayakan pemulasaraan dan pemakaman kepada rumah sakit demi menjaga keamanan.

3. Sebagian keluarga mengikuti prosesi pemakaman untuk memastikan jenazah dirawat dengan benar.

Pada tabel di atas, disajikan sebuah paragraf pendek dalam bentuk kasus tentang orang meninggal dunia di masa pandemi covid19 yang belum jelas alasan kematiannya. Dalam soal tersebut, disajikan tiga alternatif kesimpulan yang harus dinilai oleh peserta didik apakah argumen dalam kesimpulan tersebut kuat atau lemah.

Adapun untuk penskoran, setiap jawaban benar mendapatkan skor 1 dan jawaban salah atau tidak memberikan jawaban mendapatkan skor 0. Selanjutnya skor yang diperoleh dikonversi ke dalam bentuk nilai dengan rentang 0-100 dengan cara membagi perolehan skor dengan total skor kemudian dikalikan 100 sebagaimana rumus di bawah ini (Danaryanti \& Lestari, 2017).

$$
\text { Nilai akhir } \frac{\text { Perolehan skor }}{\text { Total skor }} \times 100
$$

Nilai akhir tersebut kemudian diinterpretasikan menggunakan kriteria sebagai berikut: di atas 80 berarti sangat kritis, 61-80 berarti kritis, 41-60 berarti kurang kritis, dan 25-40 berarti sangat kurang kritis (Setyowati, Subali, \& Mosik, 2011)

Berdasarkan hasil analisis menyatakan bahwa model tes WGCTA dengan kelima indikatornya sampai sejauh ini cukup relevan dengan materi-materi dalam ilmu fikih. Dengan demikian, tes WGCTA bisa dikembangkan lebih jauh dan digunakan dalam menilai kemampuan berpikir dalam bidang fikih.

\section{PENUTUP}

Dalam pembelajaran fikih, kemampuan berpikir kritis adalah kebutuhan mutlak untuk memahami hukum Islam secara logis sesuai metode berpikir yang benar. Dengan kemampuan berpikir kritis, peserta didik akan mampu untuk berpikir reflektif dan argumentatif dalam menghadapi berbagai problem keagamaan yang dihadapi di era disrupsi. Sayangnya, kemampuan berpikir kritis dalam pembelajaran fikih, dan PAI pada umumnya, selama ini tidak banyak mendapatkan perhatian. Padahal amanat Kurikulum 2013 sudah jelas bahwa kemampuan berpikir kritis merupakan kompetensi wajib bagi peserta didik di semua mata pelajaran. Karena itu, sebagai rekomendasi tulisan ini, perlu penekanan yang lebih besar terhadap kemampuan berpikir kritis dalam pembelajaran fikih ataupun bidang PAI lainnya. Ini bisa diwujudkan melalui banyak aspek, mulai perencanaan, strategi, hingga penilaian pembelajaran yang mengambil titik tekan pada kemampuan berpikir kritis. Selanjutnya, untuk mengukur kemampuan berpikir kritis dalam pembelajaran Fikih, tentu dibutuhkan model penilaian yang valid dan reliabel. Penilaian critical thinking skills model Watson-Glaser Critical Thinking Appraisal (WGCTA) bisa menjadi alternatif baru dalam penilaian pembelajaran Fikih dan PAI pada umumnya. Para pendidik bisa menerapkan WGCTA dalam penilaian PAI dengan cara mengadaptasikan lima indikator WGCTA sesuai tema-tema pembelajaran ke dalam berbagai bentuk ujian yang dilaksanakan.

\section{DAFTAR PUSTAKA}

Akbar, A. O. (2014). Konstruksi Epistemologis Penalaran Hukum Imam Syafi'i. Ahkam : Jurnal Ilmu Syariah, 14(2), 185-192. https://doi.org/10.15408/ajis.v14i2.1277 
Ali, M. H. B. (2016). Menilai Isi Kandungan Ceramah: Kajian Kes Penceramah Yang Ditauliahkan Oleh Jabatan Agama Islam Selangor (JAIS). Reflektika, 11(2), 1-1414.

https://doi.org/10.28944/reflektika.v11i2. 25

Anazifa, R. D., \& Djukri, D. (2017). ProjectBased Learning and Problem-Based Learning: Are They Effective to Improve Student's Thinking Skills? Jurnal Pendidikan IPA Indonesia, 6(2), 346355.

https://doi.org/10.15294/jpii.v6i2.11100

Bahri, F. M., \& Supahar. (2019). Kemampuan berpikir kritis menggunakan tes terintegrasi agama dan sains dalam pembelajaran PAI di SMA. Edukasi Islami : Jurnal Pendidikan Islam, 8(2), 223-252.

Bahri, S. (2011). Penerapan Kaidah Hukum Islam dalam Istinbath Hukum. Kanun Jurnal Ilmu Hukum, XIII(55), 59-74.

Baird, J.-A., Andrich, D., Hopfenbeck, T. N., \& Stobart, G. (2017). Assessment and learning: Fields apart? Assessment in Education: Principles, Policy \& Practice, 24(3),

317-350. https://doi.org/10.1080/0969594X.2017. 1319337

Bandyopadhyay, S., \& Szostek, J. (2019). Thinking critically about critical thinking: Assessing critical thinking of business students using multiple measures. Journal of Education for Business, 94(3), 259270.

Burke, B. L., Sears, S. R., Kraus, S., \& RobertsCady, S. (2014). Critical Analysis: A Comparison of Critical Thinking Changes in Psychology and Philosophy Classes. Teaching of Psychology, 41(1), 28-36. https://doi.org/10.1177/00986283135141 75

D'Alessio, F. A., Avolio, B. E., \& Charles, V. (2019). Studying the impact of critical thinking on the academic performance of executive MBA students. Thinking Skills and Creativity, 31, 275-283. https://doi.org/10.1016/j.tsc.2019.02.002
Dalimunthe, A. Y. (2019). Halaqah dan Munazharah Warisan Pendidikan Islam Klasik. Forum Pedagogik, 11(1), 15-26.

Danaryanti, A., \& Lestari, A. T. (2017). Analisis Kemampuan Berpikir Kritis dalam Matematika Mengacu pada Watson-Glaser Critical Thinking Appraisal Pada Siswa Kelas VIII SMP Negeri di Banjarmasin Tengah Tahun Pelajaran 2016/2017. EDU-MAT: Jurnal Pendidikan Matematika, 5(2), 116-126. https://doi.org/10.20527/edumat.v5i2.46 31

Ennis, R. H. (1958). An Appraisal of the Watson-Glaser Critical Thinking Appraisal. The Journal of Educational Research, 52(4), 155-158. https://doi.org/10.1080/00220671.1958.1 0882558

Ennis, R. H. (2018). Critical Thinking Across the Curriculum: A Vision. Topoi, 37(1), 165-184. https://doi.org/10.1007/s11245016-9401-4

Facione, P. A. (2011). Critical thinking: What it is and why it counts. Millbrae: Measured Reasons and The California Academic Press.

Fajrianthi, Hendriani, W., \& Septarini, B. G. (2016). Pengembangan Tes Berpikir Kritis dengan Pendekatan Item Response Theory. Jurnal Penelitian dan Evaluasi Pendidikan, 20(1), 45-55. https://doi.org/10.21831/pep.v20i1.6304

Grimard Wilson, D., \& Wagner, E. E. (1981). The Watson-Glaser Critical Thinking Appraisal as a Predictor of Performance in a Critical Thinking Course. Educational and Psychological Measurement, 41(4), 1319-1322. https://doi.org/10.1177/00131644810410 0443

Haika, R. (2016). Konsep Qath'i dan Zhanni dalam Hukum Kewarisan Islam. Mazahib, 15(2), 183-196. https://doi.org/10.21093/mj.v15i2.632

Heyboer, M. W. (2009). Journeys into the Heart and Heartland of Islam. Pennsylvania: Dorrance Publishing. 
Huber, C. R., \& Kuncel, N. R. (2016). Does College Teach Critical Thinking? A Meta-Analysis. Review of Educational Research, 86(2), 431-468. https://doi.org/10.3102/00346543156059 17

Indah, A. D., \& Fauzan, A. (2019). Analisis Kemampuan Berpikir Kritis Matematis Peserta Didik Kelas VIII SMP Negeri 3 Payakumbuh Menggunakan WatsonGlaser Critical Thinking Appraisal. Jurnal Edukasi dan Penelitian Matematika, 8(3), 124-129.

Jafar, M. (2016). Kedudukan akal dalam istinbath hukum menurut kajian ushul fiqh. Jurnal Al Mabhats, 1(1), 12-32.

Khodadady, E., \& Ghanizadeh, A. (2011). The Impact of Concept Mapping on EFL Learners' Critical Thinking Ability. English Language Teaching, 4(4), 49-60. https://doi.org/10.5539/elt.v4n4p49

Lu, D., \& Xie, Y. (2019). The effects of a critical thinking oriented instructional pattern in a tertiary EFL argumentative writing course. Higher Education Research \& Development, 38(5), 969984.

Macpherson, K., \& Owen, C. (2010). Assessment of critical thinking ability in medical students. Assessment \& Evaluation in Higher Education, 35(1), 41-54.

https://doi.org/10.1080/02602930802475 471

Ma'luf, L. (1956). Al-Munjid fi al-Lughah. Beirut: Mathba'ah al-Katsulikiyah.

Mason, M. (2007). Critical Thinking and Learning. Educational Philosophy and Theory, 39(4), 339-349. https://doi.org/10.1111/j.1469-

5812.2007.00343.x

Mendikbud RI. (2013). Peraturan Menteri Pendidikan dan Kebudayaan RI Nomor 81A Tahun 2013. Kemendikbud RI.

Mendikbud RI. Peraturan Menteri Pendidikan dan Kebudayaan Republik Indonesia Nomor 36 Tahun 2018 tentang Perubahan Atas Peraturan Menteri
Pendidikan dan Kebudayaan Nomor 59 Tahun 2014 tentang Kurikulum 2013 Sekolah Menengah Atas/Madrasah Aliyah., (2018).

Menteri Agama Republik Indonesia. Lampiran Keputusan Menteri Agama Republik Indonesia Nomor 183 Tahun 2019 Tentang Kurikulum Pendidikan Agama Islam dan Bahasa Arab pada Madrasah., (2019).

Muqoffi. (2018). Implikasi Program Bahts AlMasa'il Terhadap Nalar Kritis Santri di Pondok Pesantren Gedangan Daleman Kedungdung Sampang. KABILAH : Journal of Social Community, 3(1), 100 114.

https://doi.org/10.35127/kbl.v3i1.3275

Mustikarani, W., \& Ruhimat, M. (2018). Kelemahan dan Keungulan Implementasi Authentic Assessment dalam Pembelajaran Geografi. GEA Jurnal Pendidikan Geografi, 18(2), 147-153.

Paul, R. W. (2018). Critical Thinking and Critical Person. In Thinking: The Second International Conference. New York: Routledge.

Pelu, I. E. A. S. (2016). The Rechtsvinding Epistemology of Nahdlatul 'Ulama (NU). Journal of Law, Policy and Globalization, 53(0), 78-85.

Riem, H. H.-, Klemm, S. B.-, Mansuy, W. G.-, Hadorn, G. H., Joye, D., Pohl, C., ... Zemp, E. (2007). Ide of Handbook. In Handbook of Transdisciplinary Research. Switzerland: Springer.

SA, R. (2015). Konsep Qath'iy-Zhanniy serta Implikasinya dalam Istinbath Hukum. Intizar, 21(1), 147-163.

Schwab, K. (2017). The Fourth Industrial Revolution. New York: Crown Bussines.

Setyowati, A., Subali, B., \& Mosik -. (2011). Implementasi Pendekatan Konflik Kognitif dalam Pembelajaran Fisika untuk Menumbuhkan Kemampuan Berpikir Kritis Siswa SMP Kelas VIII. Jurnal Pendidikan Fisika Indonesia, 7(2), 89-96.

https://doi.org/10.15294/jpfi.v7i2.1078 
Shaffat, I. (2010). Epistemologi Keilmuan Hukum Islam (Sebuah Tawaran Konsep Alternatif). Al Ihkam, 5(1), 38-62.

Sulaiman, A., \& Syakarofath, N. A. (2018). Berpikir Kritis: Mendorong Introduksi dan Reformulasi Konsep dalam Psikologi Islam. Buletin Psikologi, 26(2), 86. https://doi.org/10.22146/buletinpsikologi .38660

Taufiqurrahman, Heryandi, M. T., \& Junaidi. (2018). Pengembangan Instrumen Penilaian Higher Order Thinking Skill Pada Mata Pelajaran Pendidikan Agama Islam. JPII, 2(2), 199-206.

Thonney, T., \& Montgomery, J. C. (2019). Defining Critical Thinking Across Disciplines: An Analysis of Community College Faculty Perspectives. College Teaching, 67(3), 169-176. https://doi.org/10.1080/87567555.2019.1 579700

Vieira, R. M., \& Tenreiro-Vieira, C. (2016). Fostering Scientific Literacy and Critical Thinking in Elementary Science Education. International Journal of Science and Mathematics Education, 14(4), 659-680. https://doi.org/10.1007/s10763-0149605-2

Walbridge, J. (2011). God and Logic in Islam: The Caliphate of Reason (1st ed.). New York: Cambridge University Press.

Wasik, A. (2014). Optimalisasi Nalar Kritis Santri Dalam Sistem Bahtsul Masa'il Fiqhiyah NU. LISAN AL-HAL: Jurnal Pengembangan Pemikiran Dan Kebudayaan, 8(2), 207-230.

Watson, G., \& Glaser, E. (2002). WatsonGlaser Critical Thinking Appraisal UK Edition-Practice Test. London: Pearson Assessment.

Wechsler, S. M., Saiz, C., Rivas, S. F., Vendramini, C. M. M., Almeida, L. S., Mundim, M. C., \& Franco, A. (2018). Creative and critical thinking: Independent or overlapping components? Thinking Skills and Creativity, 27, 114122.

https://doi.org/10.1016/j.tsc.2017.12.003

Yasid, A. (2012). Logika Induktif dan Deduktif dalam Tradisi Pemikiran Usul al-Fiqh. Asy-Syir'ah, 46(1), 1-26. 